\title{
EMERGING SEPARATION OF OWNERSHIP AND CONTROL IN ETHIOPIAN SHARE COMPANIES:
}

\author{
Legal AND Policy IMPlications
}

\author{
Fekadu Petros Gebremeskel *
}

\begin{abstract}
Ownership and control are often concurring attributes in the ordinary situation of property ownership. In the context of publicly held companies, a phenomenon occurs whereby the persons who own the company are precluded from controlling it. The reason for this is that as the number of shareholders rises, control is delegated to managers, and shareholders are limited to ineffective control via shareholder general meetings. This article posits that the separation between ownership and control is growing in Ethiopia, and submits some empirical evidence in support of this claim. Relying on the data and literature on corporate governance, the article attempts to show the deficiency of the Commercial Code in protecting the rights of minority shareholders in the context of such publicly held companies.
\end{abstract}

\section{Key words:}

Corporate governance, corporate control, minority shareholder rights, ownership \& control, share companies

\section{Abbreviations}

OECD Organization for Economic Co-operation and Development IPO Initial public offering

LLSV Raphael La-Porta, Florencio Lopez-de-Silanes Andrei Shleifer, and Robert W. Vishny

* LL.B, LL.M (AAU); former Arbitration Tribunal Manager at ECX; currently studies International Dispute Settlement at Geneva University Graduate Institute for International \& Development Studies. The writer thanks Ato Tadesse Melaku, Ato Elias Nour and the article's external assessors (who remain anonymous). The article has greatly benefited from their comments. The writer also thanks MoTI (Ministry of Trade \& Industry) staff for their cooperation in availing access to the Ministry's archives, and Ato Helaway Tadesse, Sr. V. President of Zemen Bank S.C, for promptly providing him with the data that was necessary for this article. For any questions or comments with regard to this work, the writer is glad to be contacted through: fekaduros@yahoo.com 


\section{Introduction}

The share company is one of the forms of business organizations recognized under the Ethiopian Commercial Code. It is established through the issuance of shares to an unlimited number of members as provided for by Articles 304-509 of the Commercial Code. The result of public subscription toward the formation of a share company is often accumulation of huge capital from thousands of shareholders.

Publicly held share companies give rise to a host of complex corporate governance issues. On the one hand, they necessitate the transfer of management of the company from the numerous shareholders into the hands of a few managers. And, such a mechanism inherently carries with it the risk of unfair advantage or exploitation by the managers against dispersed shareholders. On the other hand, should any one or more persons own a chunk of the corporate capital, control of the company will largely fall into their hands, and small holders face the same or even greater risk of exploitation.

The Commercial Code of Ethiopia has basic rules on the governance of such companies. However, these rules are not adequate to safeguard minority shareholders from undue exploitation. This article attempts to deal with what the potential problems can be and what type of legal change, if any, needs to be made to address the newly evolving corporate governance issues in Ethiopia in the context of publicly held companies for safeguarding minority rights. The article does not promise or claim to provide the panacea for all corporate governance problems in the country. Nor does it attempt to unveil the "vast corporate governance malpractices" that are assumed to exist in the country. At the current state of corporate disclosure this is almost impossible. ${ }^{1}$

\footnotetext{
${ }^{1}$ The writer had to visit the National Bank of Ethiopia (NBE) several times to get some statistical data on private banks. Unfortunately, his request was denied by the Bank's Legal Directorate, even if he had a letter of support which showed research objectives. The Banking Business Proclamation 592/2008 apparently says nothing on disclosure by the bank to the public. Quite inexplicably, such documents which should be with the Ministry of Trade and Industry (as per the requirement of the law) do not exist there in case of banks and insurance companies. However, Proclamation 592/2008, under Article 10 (5) requires all banks to make available at their head offices free of charge, to any interested person their share registers that show the names and voting rights of their shareholders. The writer's repeated attempt did not bear fruit in getting the required information from the banks either, except from one. Understandably, banks are more reluctant to disclose their documents. The realistic solution would be to give this service at the NBE or MoTI level. If it is so difficult to get shareholder data for academic purposes, it would be much more so for the investing public that
} 
The article is limited to analyzing the trend of corporate ownership dispersion, and the resulting divorce between ownership and control - a trend which renders every shareholder a minority. It also suggests solutions. The article starts with an overview of the notion, models and issues of corporate governance with the aim of laying down the conceptual bases for the subsequent discussion. The second section addresses the evolution of the ownership pattern in Ethiopia. The third and fourth sections deal with the underlying legal and institutional causes and effects of the different corporate governance paradigms. The conclusion underlines the implications of the themes addressed. In this article the terms "managers" and "board of directors" are used interchangeably.

\section{An Overview on Corporate Governance Mechanisms}

Since the usage of the term "corporate governance" by Robert Tricker in his book titled "International Corporate Governance,"2 published in 1984, the term has gained prominence in company law and literature. The issues addressed under the "corporate governance" label are, however, nearly as old as company law itself, although the notion has not been static in terms of content. Corporate governance is one of those fluid concepts in corporate law and finance which scholars rarely attempt to define. The range of issues that fall under "corporate governance" are tightly intertwined with those of corporate finance. ${ }^{3}$ For instance, as per one definition, corporate governance "deals with the ways in which suppliers of finance to corporations assure themselves of getting a return on their investment." "Such a definition seems to be too narrow to accommodate all the issues that arise in relation to modern day corporate governance, and reveals the complexities involved in the concept.

Indeed, modern corporate governance may also involve corporate social responsibility with a view to addressing the interests of employees, local communities and the public at large, and not merely the interest of suppliers of capital. It is thus not surprising to sometimes see a misconceived usage of the term. For example, Article 14 (4) (c) of the Banking Business Proclamation $592 / 2008$ which states "The National Bank may issue directives on the duties, responsibilities and good corporate governance of the boards of directors" seems to distort the idea of corporate governance. Corporate governance is not

looks for a target company's net worth. Corporate disclosure, a central facet of corporate governance, is at a rudimentary stage in Ethiopia.

${ }^{2}$ Cited in Anne Carver (1997), "Corporate Governance: Capitalism's Fellow Traveler?”, in Fiona M. Patfield, (ed.) Perspectives on Company Law:2, (London:

Kluwer Law Int.), p. 71

3 Corporate law and Corporate Governance: The Hungarian Experience,

$<$ http://www.econ.core.hu/doc/dp/dp/mtdp0411.pdf > p.4

${ }^{4}$ Ibid. 
just a single strand in the managerial duties of the board of directors.' Quite to the contrary, the notion of 'corporate governance' refers to the overall legal, institutional and regulatory framework in which the interests of stakeholders surrounding companies are coordinated and protected. Note that the concept is much wider than corporate management. The latter notion occupies a pivotal place in the discourse of corporate governance, but does not replace it. Broad as it is, corporate governance is generally shaped by not only company law, but also other areas of laws and customs such as auditing and accounting practices, contract law, bankruptcy law, securities law, tax law, and so on.

The role that corporate business plays in modern economies has brought companies to the spotlight. Thus, corporate governance nowadays refers to all the issues in relation to ownership and control of corporate property, shareholders' rights and treatment, powers and responsibilities of the board of directors, disclosure and transparency of corporate information, the protections of the interests of stakeholders in addition to that of shareholders, enforcement of rights, etc. ${ }^{5}$ What lies at the heart of all these issues is the question of ownership and control of the company which is inextricably correlated with ownership of its shares.

The macro level causes and effects of demutualization of ownership and control permeate the corporate governance debate. ${ }^{6}$ Meanwhile, the rights, responsibilities and roles of owners of property in the form of shares and its managers remain to be an enduring problem. With the emergence of companies with several thousands of shareholders (each possibly holding less than a fraction of one percent of the capital), complete separation occurs between ownership (vested in the shareholders) and control, which lies in the hands of few individuals who manage the company. ${ }^{7}$ Within this context, a host of governance issues inevitably arise some of which are summarized below.

Corporate governance problems begin from the danger to shareholders' most traditional right to dividend and extend to such complex issues as protection of corporate assets from misuse by managers, minority rights to representation in the board, challenging the decision of the board in a court of law, suing the board or third parties on behalf of the company, and leaving the company upon free will, etc. ${ }^{8}$ Moreover, there is an important subject of the

${ }^{5}$ Corporate Governance in Developing Countries: Shortcomings, Challenges and Impact on Credit <http://www.uncitral.org/pdf/english/congress/Cooper_S_rev.pdf > p. 3 .

${ }^{6}$ See Generally, Raphael La-Porta, Florencio Lopez-de-Silanes, Andrei Shleifer, and Robert W. Vishny (1998)," Law and Finance", Journal of Political Economy, 106\# 6.,

${ }^{7}$ See generally Adolf Berle and Gardner Means (1933), The Modern Corporation and Private Property (New York: The Macmillan Company).

${ }^{8}$ All these issues are elaborated in detail in, OECD Principles of Corporate Governance, (2004). 
corporate governance controversy which relates to the powers and responsibilities of the board. This raises crucial issues such as: what powers does the board have? Who is it accountable to? How is it organized? What are its standards of liability? Another pertinent issue relates to the disclosure of information to the shareholders and the public by the company for which the management is responsible. What, when, and how to disclose corporate information are very relevant questions in modern corporate climate.

Moreover, the role of stakeholders, which, needless to say, is a far more complex issue, seems to be the latest addition to the stock of themes addressed within the gamut of corporate governance. It has in fact, to some extent, reshaped the very conception of a company. Thus issues such as what are the legitimate ends of corporate business? what, if any, are the social responsibilities of the company, etc. are addressed within this context. And finally, traversing all these issues is the question of enforcement of rights. Indeed, this is where corporate governance and the issue of good governance (raised at the political landscape) converge. Effective enforcement of rights of various stakeholders is indeed indispensable, in addition to and apart from the literal articulation of laws.

These issues can be broadly divided into two classes. (1) The intracompany issues (issues of ownership and control); and (2) the relationship between the company and outer stakeholders such as employees, creditors, local communities and the general public. Although the theme of this article falls within the former, the discussion that will follow addresses the problem from the perspective of minority rights protection.

\section{1- Modalities of Corporate Control}

Minority rights discourse is generally part of corporate ownership and control discourse. Hence, a few preliminary points about corporate control need to be said. The concept of corporate ownership in the present context refers to ownership of the shares in a company. Despite some controversy as to who owns a company ${ }^{9}$, the article assumes that for all practical purposes, the company is the collective property of its shareholders. Thus, there is no need to discuss the notion of corporate ownership here.

In the corporate climate, control can be organized in various ways. In its most natural form control can be exercised through complete ownership of the

$<$ http://www.oecd.org/dataoecd/32/18/31557724.pdf >

9 Charles De Hoghton (1970), The Company: Law, Structure and Reform in Eleven Countries (London, George Allen and Unvin Ltd.), p,33; John Kay and Aubrey Silberston (1997), "Corporate Governance", in Fiona M. Patfield (eds.) Perspectives on Company Law: No. 2 (London: Kluwer Law Int.), pp. 52 - 54. 
company. Such is usually the case under Ethiopian law, for example, when five persons form a share company and run it either by themselves or by their hired managers whom they can freely remove. ${ }^{10}$ The second form of creation of control is by majority ownership. As the size of companies and shareholders grows, complete ownership gives way to part ownership. The ownership of a majority of the shares by an individual or small group of individuals gives to the individual or the group virtually all the powers of control, in particular the power to select and remove the board of directors. ${ }^{11}$

Corporate control can also be created by legal devices with neither complete nor majority ownership. Such legal arrangements include pyramiding and the use of non-voting shares. Non-voting shares preclude certain group(s) of shareholders from taking part in corporate decision making in exchange for some benefit. Article 399(2) of the Commercial Code envisages this possibility. But the proportion of such non-voting shares cannot exceed half of the share capital under Ethiopian law. ${ }^{12}$ Pyramiding involves "the owning of a majority of the stock of one corporation which in turn holds a majority of the stock of another-a process which can be repeated a number of times." 13 With the setting up of two or more intermediate companies each of which is controlled by majority ownership of its stock by the company higher in the series, "complete legal control of a large operating company can be maintained by an ownership interest equal to a fraction of one percent of the property controlled."14

The other, perhaps the last scheme in the evolution of corporate control in modern capitalism is what is known as management control which results from dispersion of share ownership, save the possibility of existence of a block-holder under certain circumstances. When the largest single shareholding amounts to a fraction of one percent of the capital, no shareholder is "in a position through his holding alone to place important pressure upon the management or to use his holding as a considerable nucleus for the accumulation of the majority of votes necessary to control." 15 Thus, control over the company remains in the hands of the management.

\section{2- Share Ownership Pattern and Governance Models}

Corporate governance styles differ across different legal systems. No two countries can be similar in absolutely every respect, and thus countries have

\footnotetext{
${ }^{10}$ Commercial Code of Ethiopia Article 307(1) cum Article 317.

${ }^{11}$ Berle \& Means, supra n. 7, p.71, See also Article 350(1) \& (2) cum Article 419 (2) \& 421(3), and Article 365 of the Commercial Code of Ethiopia,1960.

${ }^{12}$ Id , Article 36(3) \&(4).

${ }^{13}$ Berle \& Means, supra n. 7, p. 72.

14 Ibid.

15 Ibid.
} 
diversity. Therefore, corporate governance scholars categorize legal systems along lines of broadly shared systems and institutions. On the basis of patterns of ownership and control, the corporate governance literature typically distinguishes two major corporate governance models: one based on equity finance and control primarily by capital markets with a characteristic feature of diffuse ownership; and the other based on debt finance and control by banks in the dual role of shareholders and major creditors" with a characteristic concentration of ownership. ${ }^{16}$ Equity (share) financing and control by capital markets characterize the Anglo-American corporate governance paradigm, and debt financing and control by banks is typically associated with the corporate governance style of Germany and Japan. ${ }^{17}$

\subsection{1- The Dispersed Ownership Model}

For the most part of the $20^{\text {th }}$ century and henceforth, the US, UK and most of the English speaking world have consistently maintained dispersion of ownership and its concomitant consequence of separation of control and ownership. ${ }^{18}$ Dispersed ownership model of corporate governance is characterized by "strong securities markets, rigorous disclosure standards, and high market transparency, in which the market for corporate control constitutes the ultimate disciplinary mechanism" on management. ${ }^{19}$ Therefore, publicly held companies in the US and UK have a higher rate of dispersion of ownership compared to their Civil Law counterparts. ${ }^{20}$

Diffuse ownership emerges in many ways. While some companies may undergo different stages of development before they are held by the broader public, many publicly held companies are outrightly established by a public offering of shares. ${ }^{21}$ In some other cases smaller family held companies may go public by offering their shares to the public. ${ }^{22}$ Such a change is often motivated

\footnotetext{
${ }^{16}$ Katharina Pistor (2000), Patterns of Legal Charge: Shareholder and Creditor Rights in Transition Economies (European Bank Working Paper No.49), p. 21.

${ }^{17}$ Ibid.

${ }^{18}$ See Generally, Brian R. Cheffins (2002), "Corporate law and Ownership Structure: A Darwinian Link?, University of New South Wales Law Journal, 25 \#2; See also, The Berle-Means Corporation in the $21^{\text {st }}$ Century. $<$ http://www.law.upenn.edu/currently/seminars/businesslawscholarship/papers/Gord on.pdf >

${ }^{19}$ John D. Coffee (2001), "The Rise of Dispersed Ownership: The Role of law and State in the Separation of Ownership and Control," The Yale Law Journal, 111 \# 1, p.3.

${ }^{20} I d .$, p. 56.

${ }^{21}$ See the Commercial Code of Ethiopia, Articles 317-322; See also Tom Hadden, (1977) Company Law and Capitalism, 2nd ed. (London: Weidenfeld and Nicholson), p. 298.

${ }^{22}$ Coffee, supra n. 19, p. 25.
} 
by the need for a huge capital for business expansion. Still in other cases, state enterprises may be transformed into publicly held companies by adopting privatization through offering shares to the public. ${ }^{23}$

Anglo-American companies exhibit the largest number of companies with diffuse ownership. An empirical study conducted by La Porta, Lopez de Silanes, Shleifer and Vishny (hereinafter referred to as LLSV) compared stock ownership patterns in countries that follow the Anglo American model, the Scandinavian Model, the German Civil Law model, and the French Civil Law model (the latter three are commonly referred to as Civil Law models). The study found that followers of the Anglo-American model exhibit the lowest level of concentration of ownership, or the highest level of dispersion. ${ }^{24}$ For example, a comparison of the combined average stake of the three largest shareholders in the top ten publicly held companies yielded only $20 \%$ in the USA. French Civil Law system scored the highest average concentration of ownership of 54\%, while the average combined block of three largest shareholders in the German Civil Law family was 34\% and that of the Scandinavian was $37 \% .^{25}$ The USA of course seems to have experienced dispersion of corporate ownership much earlier. As of 1929, the combined block of shares of the twenty largest shareholders in each of the biggest companiesPennsylvania Railroad, Pennsylvania Telecom Company, and Pennsylvania Steel Company- were respectively 2.7, 4.0 and 5.1 percent. $^{26}$

High level of dispersed ownership means absence of owners of big blocks of shares (block holders). In a company with numerous shareholders, the absence of such block holders gives rise to the surrender by shareholders of control to managers. ${ }^{27}$ The lack of control by shareholders is generally attributed to lack of collective action or problems in coordination. Shareholders in a publicly held corporation typically have limited legal right to engage in its day to day management. ${ }^{28}$ Each of the dispersed small holders will thus have little

${ }^{23}$ Unfortunately in Ethiopia, Privatization of Public Enterprises Proclamation 146/1998 fails to state this mode of privatization; See Article 5(2) cum Article 7.

${ }^{24}$ La Porta et al, supra n. 6, p. 1146.

${ }^{25}$ Ibid, p. 1147.

${ }^{26}$ Berle \& Means, supra n. 7, p.47.

${ }^{27}$ id., p. 6. Even in the $19^{\text {th }}$ century, Karl Marx had asserted that "stock companies in general...have an increasing tendency to separate [the] work of management as a function from the ownership of capital, be it self owned or borrowed", see Karl Marx, Capital (Republished, 1973), Vol.III, (New York: International Publishers), pp. 387-388.

${ }^{28}$ Stephen G. Markes (1999), “The Separation of Ownership and Control”, in Bouckaert, Boudewijn and De Geest, Gerrit (eds.), Encyclopedia of Law and Economics, 3, p. 629. 
information and much less motivation to monitor the management. Though dispersed small holders can become powerful by coming together, the cost of making such coordinated action is often high. Even voting in which shareholders are expected to be more organized has often been manipulated by the managers to the latter's advantage. ${ }^{29}$

The managers may thus be lured to using their control over corporate assets to promote their own interests at the expense of that of the shareholders. To the extent that the management pursues its own interests at the expense of the shareholders, it imposes what economists call "agency cost." ${ }^{30}$ Concern over agency cost in widely held public companies was expressed even much earlier. Adam Smith, in the Wealth of Nations, 1776 had said:

The directors of such companies [. . .], being the managers rather of other peoples' money than of their own, it cannot well be expected that they should watch over it with the same anxious vigilance with which the partners in a private co-partnery watch over their own. Like the stewards of a rich man, they are apt to consider attention to small matters as not for their master's honor, and very easily give themselves a dispensation from having it. Negligence and profusion, therefore, must always prevail, more or less in the management of the affairs of such a company. ${ }^{31}$

While agency cost can never be completely avoided, the Anglo-American style of corporate governance has its inbuilt system of reducing it. There are three mechanisms of minimizing agency cost. First, the labour market for corporate executives has a disciplinary role on the conduct of managers. Managers want to perform well in order to impress potential employers at a better term. ${ }^{32}$ Secondly, bad management which sufficiently causes a decline in the market share for products or services can cost management its job. ${ }^{33}$ The most effective disciplinary tool in the widely held company however is the third mechanismhostile takeover. Hostile takeover occurs when shareholders unhappy with the performance of their company opt to walk out by selling their shares to a control bidder. If managers perform persistently badly, an outsider may take over by buying a majority of the shares through a hostile takeover i.e., one rejected by managers but accepted by shareholders. ${ }^{34}$

29 bid.

${ }^{30}$ Supra n. 28, P. 695; See also, Enya He and David A. Sommer, Separation of Ownership and Control: Implications for Board Composition, $<$ http://www.aria.org/meetings/2006papers/He_Sommer_ARIA_2006.pdf > p. 6

${ }_{31}^{31}$ Adam Smith (1776), The Wealth of Nations, Book 5, Chapter 1, Part 3, Art. 1.

${ }^{32}$ Cheffins, supra n. 18, p. 17.

${ }^{33}$ Ibid.

${ }^{34}$ Carver, supra n. 2, p. 86. 
The risk of losing one's job following a takeover can thus serve as one of the means that can discipline management. Other means of reducing agency cost include specifying managerial duties legislatively, administratively, or contractually and putting in place effective enforcement mechanisms. In this respect, enforcement mechanisms by public regulatory organs, private selfregulation (such as stock exchanges) and individual rights of action (in derivative and/or class action) are very instrumental. ${ }^{35}$

The Anglo-American model has other virtues as compared with systems characterized by concentrated ownership. To begin with, the separation of ownership and control often carries with it the benefit of hiring more qualified managers since executives are hired on the basis of their managerial credentials, than on their ability to finance the firm or their family connections with dominant shareholders. ${ }^{36}$ The absence of block holders also creates a convenient working environment for professional managers since small dispersed owners are ubable to interfere with the business of the management. Thus, the agency cost problem may to some extent be offset by this benefit.

From the capital markets perspective, dispersed ownership brings high liquidity to stock markets and cheapens the cost of capital ${ }^{37}$ provided there is a stock market in place. Clearly, dispersion of ownership and stock market liquidity tend to mutually reinforce each other. More dispersion results in more liquidity as there will be more market participants. On the other hand, the more liquid the stock market, the easier it becomes for shareholders to liquidate their holdings thereby making exit easier for unhappy shareholders. Shareholder exodus also plays the role of monitoring management to some extent, since such act of shareholders reflects on the state of the company, and eventually leads its stock prices to fall. The existence of a liquid market encourages investors to easily buy or sell securities. Dispersed ownership of stocks has also the economic benefit of distribution of risk, in comparison to the concentrated ownership model where few block holders bear all or most of the risks of businesses. $^{38}$

35 George Bittlingmayer (1999), "The Market for Corporate Control (Including Takeovers)", in Bouckaert, Boudewijn and De Geest, Gerrit (Eds.), Encyclopedia of Law and Economics, 3, p. 703.

${ }^{36}$ Cheffins, supra n 18 , p. 4.

${ }^{37}$ Terry O’Neill (1997), "The Patriarchal Meaning of Contract: Feminist Reflections on the Corporate Governance Debate", in Fiona M. Patfield (Ed.), Perspectives on Company Law:2, (London: Kluwer Law Int.), p. 36.

${ }^{38}$ This seems to be the explanation behind the current Ethiopian Banking Business Proclamation No. 592/2008 which under Article 11(1) limits maximum holding of a shareholder to $5 \%$ in the following words: 


\subsection{2- Concentrated Ownership Model}

The concentrated ownership model is essentially characterized by the existence of controlling block holders in the company. Often, countries with this paradigm of corporate governance tend to have weak securities markets, and low disclosure and market transparency standards. As opposed to the case in diffuse ownership governance systems, only a modest role is played by the market for corporate control, a greater part of the monitoring role being played by large banks. ${ }^{39}$ According to the data compiled by LLSV, most of Civil Law legal systems exhibit this system of corporate governance with varying degrees. The two systems that form a good representative model in contrast with the dispersed ownership style are Germany and Japan. In Germany for instance, as of 1997, "eighty-nine percent of all listed companies have a single shareholder controlling more than twenty percent of their equity." necessarily mean that there are no small holders in Germany and Japan that have tiny fractions of corporate capital, it is obvious that where there are a few block holders, the latter exercise greater corporate power thereby suppressing the small holders.

An immediate effect of the concentrated ownership model on stock market development seems to be negative. The reason is that large block holders that wield corporate power may not easily liquidate their holding or more technically do not change their market positions, negatively affecting liquidity. Secondly, the few small holders cannot create enough liquidity as the volume of stocks on the market will be lower. On the other end of the spectrum, small investors will not be ready to buy shares for fear of domination by block holders. A study comparing Continental stock market practice with that of the Anglo-Saxon concludes that, in Continental models, such as the German and Japanese systems, "stock market liquidity is not an issue . . Accounting information is often murky. There is only limited protection against insider trading. As a result stock markets play a lesser role than the Anglo-American model."

The threats that dominant shareholders pose on minorities are too complex and can hardly be explained in this article. Arranging for purchase of additional shares on favorable terms which is not available otherwise, is just one of many

"No person, other than the Federal Government of Ethiopia, may hold more than

five percent of a bank's total shares either on his own or jointly with his spouse or with a person who is below the age of 18 related to him by consanguinity to the first degree."

${ }^{39}$ Coffee, supra n. 19 , p. 3.

${ }^{40}$ Ibid, p. 23.

${ }^{41}$ Carver, supra n. 2, p. 86. 
examples. ${ }^{42}$ In other cases, block-holders may transfer corporate assets by orchestrated transaction with related companies that skim profits from a publicly quoted firm in favor of privately owned ones. ${ }^{43}$ It is also possible for block holders to extract benefits "via high pay and bonuses for employed family members and associates, inappropriate related party transactions, systematic bias in business decisions and changes in the capital structure, through special issuance of shares favoring the controller." 44 In a study, on shareholder and creditor rights in transition economies, Katharina Pistor concludes that "firms with highly concentrated ownership typically have a shareholder whose stake is large enough to effectively control management. The strong position of a block holder may, however, endanger the position of minority shareholders" 45

Even when no fraud is involved, the interests of block holders seem to be susceptible to conflict with minority interests. Block holders (being big investors) often prefer a strategy of long term return on their investment, which may easily come in square conflict with minority shareholders, who seek immediate return. One solution for this problem is to make distribution of dividends compulsory for years ending in net profits. Indeed, countries that adopted their laws from France have rules that require companies to pay out a certain fraction of their declared earnings as dividends. ${ }^{46}$ In Ethiopia too, Article 456 (1\&2) of the Commercial Code compels the distribution of net profit to shareholders as dividend after deduction of legal reserve.

The foregoing analysis should not be taken as an unqualified rejection of concentrated ownership and of block-holder governance. Concentrated ownership continues to be as prevalent a choice, as that of dispersed ownership. As the relative effect of a governance model on corporate performance has not been agreed upon among scholars, no one model can get an unqualified endorsement or an outright rejection. ${ }^{47}$

First of all, if diffuse ownership creates problem of agency cost, the logical converse of this should be true, i.e., concentrated ownership must reduce this cost. The reason for this is simple. Often, "block holders will tend to be efficient monitors than dispersed shareholders. To elaborate, controlling shareholders are

${ }^{42}$ Cheffins, supra n. 18 , p. 24.

${ }^{43}$ Ibid; In Ethiopia the recent governance havoc in Bank of Abyssinia is exemplary of the problem block holders can cause to management. The bank was reported to have lost $75 \%$ profit in year 2007/2008 due to dominant shareholders who interfered in management's roles. See Capital Oct. 252009 Edition.

${ }_{44}^{44}$ Annotations to OECD Principles, supra n. 8, p. 42.

${ }^{45}$ Pistor, supra n. 16, p. 11.

${ }^{46}$ La Porta et al, supra n. 6, p.1132.

${ }^{47}$ Cheffins, supra n. 18, p. 27. 
likely to have a financial stake which is large enough to motivate them to keep a careful watch on what is going on" around the company. ${ }^{48}$ The other benefit of concentrated ownership is that the presence of large block-holders such as a family yields competitive economic advantages stemming from continuity and long term orientation. In this respect, the Anglo-American dispersed ownership model is criticized for its features of unhealthy orientation towards short term profits. ${ }^{49}$ The "financial institutions which collectively own much of the equity in American and British publicly held companies have been identified as the primary sources of this bias." ${ }^{, 00}$

\section{The Evolution of Ownership and Control in Ethiopian Share Companies}

The Commercial Code of Ethiopia has been facilitating the formation of share companies since its enactment in $1960 .{ }^{51}$ However, the formation of Share Companies was suspended during the Military Regime and was resumed only during its final years when it issued a policy of mixed economy and mainly after the collapse of the regime in 1991. Most of the companies formed at the beginning were private limited companies. For example among the 125 companies formed from 1991 till the end of 1993, 119 were private limited companies and only 6 were share companies. ${ }^{52}$ Although the rate of company formation improved subsequently, it was the number of private limited companies that increased at an accelerated rate as opposed to that of share companies (See table 1 below). Most of the share companies formed during this period often had five or a few more members. It was only since roughly 2005 that share companies ${ }^{53}$ started selling shares to the wider public and thereby started creating bigger shareholding base.

${ }^{48}$ Ibid, p. 19.

${ }^{49} \mathrm{Ibid}, \mathrm{p} .21$. It is to be recalled that the capital markets of US and UK were accused of being responsible for the current global financial meltdown due to their admitted character of motivating greedy short term oriented high risk appetite.

${ }^{50}$ Ibid.

${ }^{51}$ J.D. Von Pischke (1968), Shares and Share Trading in Addis Ababa, (Addis Ababa, College of Business Administration, Hailesillassie I University), p. 4, note 1.

52 Abu Girma (1994), "Problems and Prospects for the Emergence of a Stock Market in Ethiopia," in Getachew Yoseph and Abdul Hamid Bedri Kello (Eds.), The Ethiopian Economy: Problems and Prospects of Private Sector Development (Addis Ababa, Proceedings of the Third Annual Conference on the Ethiopian Economy), p.217.

${ }^{53}$ Companies such as Hibret Bank S.C and Wogagen Bank S.C, Fana School, Yetebaberut Beherawi Petroleum, etc were among the precursors of public offerings of shares since 1990s E.C. 
Table 1: The number of companies formed in the period 1996-end of July 2001 E.C (i.e. 2003 to 2009 G. C.)

\begin{tabular}{|l|c|r|}
\hline Year in Gregorian Calendar & Share Companies & $\begin{array}{c}\text { Private Limited } \\
\text { Companies }\end{array}$ \\
\hline 11 Sept. 2003-10 Sept. 2004 & 17 & 604 \\
\hline 11 Sept. 2004-10 Sept. 2005 & 14 & 2382 \\
\hline 11 Sept. 2005-10 Sept. 2006 & 11 & 1437 \\
\hline 11 Sept. 2006-10 Sept. 2007 & 30 & 1097 \\
\hline 11 Sept. 2007-10 Sept. 2008 & 17 & 1113 \\
\hline 11 Sept. 2008-6 August 2009 & 21 & 947 \\
\hline
\end{tabular}

Source: The Trade Registry at the Ministry of Trade and Industry

The last two years (i.e., 2008 and 2009) in Ethiopia have seen an unprecedented growth in the number of companies under formation through initial public offer of shares (IPOs). While this has helped the companies to mobilize large amounts of capital from the public, it has also brought about the dispersion of corporate ownership among several thousands of shareholders in each of these companies. The trend in dispersion is at least partly the result of the design of company promoters who not only lower the minimum shareholding threshold to enable small income group to buy shares, but also provide the upper limit of share subscriptions preventing the emergence of block holders. ${ }^{54}$

The separation of ownership and control can practically become complete where no shareholder has more than a fraction of one percent of the capital. But it should also be borne in mind that separation of ownership and control will definitely be incomplete even when there are several thousands of holders with a fraction of one percent of the capital, if one person has a big block of shares enabling him/her to exercise control. On the other hand, a company with just a hundred or more shareholders may exhibit a clear separation if the distribution of shares is more or less even. (See $e^{*}$ in table 2 below) Therefore, separation of ownership and control does not necessarily require the existence of thousands of shareholders in a given company.

${ }^{54}$ Among the fifteen initial public offerings (IPOs), most of which offering more than 100 million capital reviewed for this article, 11 had 5000 ETB (5 shares) as the minimum shareholding; while the maximum allowed in thirteen of the cases was 5 percent of the total shares offered. 
Table 2: Ownership pattern in some of the non financial companies

\begin{tabular}{|c|c|c|c|c|}
\hline Name of Company & 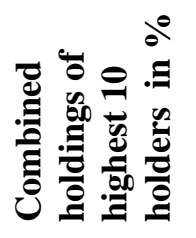 & 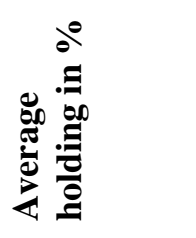 & 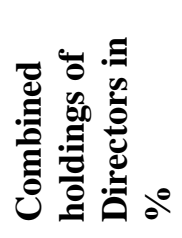 & z \\
\hline Cheha Business S.C & 5.64 & 0.564 & 3.954 & $177 *$ \\
\hline $\begin{array}{l}\text { Ehil Berenda Ehil } \\
\text { Negadewoch S.C } \\
\end{array}$ & 9.0 & 0.909 & 6.363 & $110^{*}$ \\
\hline Papirus school S.C & 3.89 & 0.432 & 3.03 & 231 \\
\hline Shola S.C & 4.295 & 0.359 & 7.51 & 110 \\
\hline Sky Bus S.C & 1.138 & 0.020 & 0.399 & 2793 \\
\hline $\begin{array}{l}\text { Yeshera Tera Berhan Limat } \\
\text { S.C }\end{array}$ & 6.57 & 0.657 & 5.921 & $152^{*}$ \\
\hline Crystal Tannery S.C** & 6.666 & 0.083 & 2.583 & 630 \\
\hline
\end{tabular}

Source: Ministry of Trade and Industry

*All the shareholders in these companies have evenly equal number of shares.

**Source: interview with the Company's General Manager, on 7 July 2009.

Table 3: Ownership pattern in some of the banks

\begin{tabular}{|c|c|c|c|c|c|}
\hline Name & 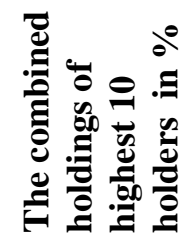 & 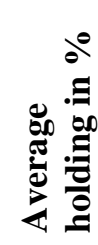 & 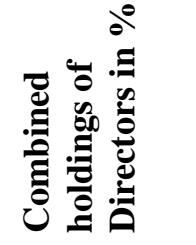 & 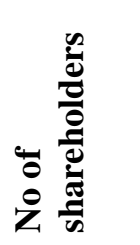 & 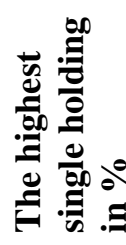 \\
\hline Brehan Int. Bank* & undisclosed & 0.016 & undisclosed & 6000 & $1.4 \%$ \\
\hline Buna Bank** & undisclosed & 0.008 & undisclosed & 11,200 & $0.9 \%$ \\
\hline Zemen Bank *** & 9.37 & 0.034 & 1.659 & 2,878 & $2 \%$ \\
\hline $\begin{array}{l}\text { Awash Int. } \\
\text { Bank**** }\end{array}$ & undisclosed & 0.037 & undisclosed & 2700 & $\begin{array}{l}\text { Undis- } \\
\text { closed }\end{array}$ \\
\hline
\end{tabular}

Source:*Reporter, 11 Oct, 2009 Edition ;**Addis Fortune, 4 Oct. Edition; ***Zemen Bank; ****http://awash-international-bank.com/Governance\%20home.html

The above data shows that there is a movement especially in the financial sector and since very recently in other sectors as well from a closely held company towards more and more broad based share ownership. At present, there are many more companies with IPOs (Initial Public Offerings). 


\section{The Causes of Diffuse/Concentrated Models of Governance}

Various explanations, which are at times contradictory, are given about the emergence of particular models of governance in a given country. A persuasive explanation in this regard is made by LLSV, who argue that the particular pattern of corporate governance in a given country is determined by the degree of protection that its law gives to minority shareholders. ${ }^{55}$ While, therefore, strong minority right protection gives rise to diffuse ownership ${ }^{56}$, weaker protection tends to discourage such pattern of ownership and gives way to block-holding. ${ }^{57}$ Other theories advanced to explain the prevalence of one pattern of governance over the other include, trade policy, size of a country's economy, political ideology, etc. ${ }^{58}$

\section{1- Level of Minority Right Protection}

The concept of minority shareholder protection is relative and can only be explained in relative terms. In order to minimize arbitrary conceptions, researchers analyze it on the basis of selected indices. A more systematic presentation of the analysis is that of LLSV as reproduced below. ${ }^{59}$ One thing to be noted is that the indices are concerned solely with shareholder rights during voting in general meetings because that is how shareholders exercise power in a company. ${ }^{60}$ These indices (on Table 4, below) are also in conformity with the OECD Principles on Corporate Governance. ${ }^{61}$

${ }^{55}$ La Porta et al, supra n. 6, pp. 1116, 1145.

${ }^{56}$ A corporate ownership can be said diffuse if the shares are owned or held by hundreds or thousands of shareholders none of whom own more than a fraction of one percent of the company's capital. Even when one or more shareholders own more than one percent an ownership structure will be diffuse, if the percentage of

${ }^{57}$ Ibid. capital held is not large enough to enable the holder to control the company.

${ }^{58}$ Brian R. Cheffins, Comparative Corporate Governance and The Australian Experience: A Reform Agenda, $<$ http://papers.ssrn.com/sol3/papers.cfm?abstract_id=268935> p. 30.

${ }^{59}$ La Porta et al, supra n. 6, p.1122.

${ }^{60}$ Id., p. 1126.

${ }^{61}$ Except the one-share one vote standard on which OECD Principles do not take a position, (see OECD Principles on Corporate Governance, Supra n 7, p.41) the rest are either expressly stated, or fall within the broad languages of the Principles. Part II, C.4 provides the right of proxy voting, Part III. A.5 broadly states the importance of making exercise of voting rights in general meetings simple. It disapproves preconditions to exercise voting rights, which obviously includes conditions such as depositing shares during general meetings. The annotations to the Principles state cumulative voting, pre-emptive right to purchase newly issued shares, derivative suit mechanisms, p. 42. 
Table 4: Minority shareholder protection index

\begin{tabular}{|l|l|l|}
\hline & Variable & \multicolumn{1}{|c|}{ Description } \\
\hline 1 & Proxy voting by mail allowed & $\begin{array}{l}\text { Equals one if the law allows shareholders to } \\
\text { mail their proxy vote to the firm, and zero } \\
\text { otherwise }\end{array}$ \\
\hline 2 & $\begin{array}{l}\text { Shares not blocked before } \\
\text { meeting }\end{array}$ & $\begin{array}{l}\text { Equals one if the law does not allow firms to } \\
\text { require that shareholders deposit their shares } \\
\text { prior to a general shareholders meeting thus } \\
\text { preventing them from selling those shares for } \\
\text { a number of days, and zero otherwise. }\end{array}$ \\
\hline 4 & $\begin{array}{l}\text { Cumulative voting or } \\
\text { proportional representation }\end{array}$ & $\begin{array}{l}\text { Equals one if the law allows shareholders to } \\
\text { cast all their votes for one candidate standing } \\
\text { for election to the board of directors } \\
\text { (cumulative voting ) or if the law allows a } \\
\text { mechanism of proportional representation in } \\
\text { the board by which minority interests may } \\
\text { name a proportional number of directors to } \\
\text { the board, and zero otherwise. }\end{array}$ \\
\hline 5 & $\begin{array}{l}\text { Oppressed minority } \\
\text { mechanisms }\end{array}$ & $\begin{array}{l}\text { Equals one if the law requires that ordinary } \\
\text { shares carry one vote per share, and zero } \\
\text { otherwise. Equivalently this variable equals } \\
\text { one when the law prohibits the existence of } \\
\text { both multiple voting and non-voting ordinary } \\
\text { shares and does not allow firms to set a } \\
\text { maximum number of votes per shareholder } \\
\text { irrespective of the number of shares owned, } \\
\text { and zero otherwise. }\end{array}$ \\
\hline $\begin{array}{l}\text { Equals one if the law grants minority } \\
\text { shareholders either the judicial venue to } \\
\text { challenge the decisions of management or of } \\
\text { the general meeting, or the right to walk out } \\
\text { of the company by requiring the company to } \\
\text { purchase their shares when they object to } \\
\text { certain fundamental changes such as merger, } \\
\text { asset dispositions and changes in the articles } \\
\text { of association. The variable equals zero } \\
\text { otherwise. Minority shareholders are } \\
\text { shareholders who collectively own 10 percent } \\
\text { or less of the share capital. }\end{array}$ \\
\hline
\end{tabular}


Countries that score one point for each of these variables obtain five points. What the hypothesis shows is that while there is no country whose legal system scores zero for all the five variables, those countries following the Common Law tradition consistently score the highest. ${ }^{62}$ Some countries from the French Civil Law tradition such as Chile scores 5 points and Norway from Scandinavian Civil law 4 points. Otherwise the average for Civil Law traditions is 2.33, Scandinavian 3.0, and that of the Common Law is $4 .{ }^{63}$ Among African countries, South Africa scores 5 points and Kenya, Nigeria and Zimbabwe each score 3 points and Egypt scores 2 points. With the exception of Egypt all have Common Law systems. ${ }^{64}$

The LLSV study analyses forty-nine developed and developing economies. In contrast, Pistor's analysis is limited to transition economies in Eastern Europe. That may explain the slight difference in emphasis between the two sets of indices. Pistor's indices are the following. ${ }^{65}$

1. The right to proxy voting by mail;

2. Absence of the obligation provided by law compelling shareholders to deposit their shares prior to shareholders' meeting;

3. Cumulative voting or proportional representation of minorities on board of directors;

4. Legally recognized right of shareholders to sue directors or to challenge the decisions of shareholder meetings in court;

5. The minimum percentage of share capital that entitles a shareholder to call ordinary general meeting is less than or equal to 10 percent; and

6. Shareholders have pre-emptive rights when new shares are issued that can be waived only by a shareholder vote.

If we look at the Commercial Code of Ethiopia, two of these rights (under number 5 and 6) are provided clearly. Voting by proxy is provided in Articles 398(1) and 402 but no voting by mail is allowed. Hence the score for that will be zero as per the LLSV index. Note that the importance of this right is stressed by the OECD Principles on Corporate Governance Part II.C.4. The minimum percentage required for shareholders to call general meetings is $10 \%$ of the capital under Article 391(2). Likewise, the pre-emptive right of shareholders to buy newly issued shares in proportion to their shareholding is unequivocally

${ }^{62}$ La Porta et al, supra n. 6, pp.1130-1131.

${ }^{63}$ Ibid.

${ }^{64}$ Ibid.

${ }^{65}$ Pistor, supra n. 16, p.5. 
provided under Article 345(4) and 470(1). This too is in compliance with the OECD Principles on minority rights as reflected in the Annotations. ${ }^{66}$

But the most important minority protection provisions seem to be those under 2, 3 and 4 of Pistor's index (that are also partly provided under LLSV index $2 \& 3$ ) which the Commercial Code fails to provide for. Article 401 of the Code specifically requires shares to be deposited during shareholder meetings. Hence Ethiopia's score for index number two in LLSV, will be zero. Cumulative voting and minority representation in the board are alternative mechanisms of minority right protection. Cumulative voting relates to voting during board elections in which the votes of the contending groups will be multiplied by the number of board seats and calculated for the contenders' nominees in accordance to the proportion of each group's summed up votes. This essentially avoids a majority-take-all outcome. Annotations to OECD Principles Part III.A.2 suggest cumulative voting as a mechanism of minority right. ${ }^{67}$

While cumulative voting is one means of ensuring proportional representation, the method envisaged under Article 52 surely is not. Article 352 calls for proportional representation in boards and reads as follows:

\section{Article 352 -Right of a minority}

Where there are several groups of shareholders with a different legal status, the articles of association shall provide for each group to elect at least one representative on the board of directors.

What this article provides is not sufficiently clear. First, what is a legal status? Is the law referring to the class of shareholders under Articles 335, 336 and 337 ? In other words, it seems to require a situation where shareholders are divided into several groups with each shareholder having some internal bond by which to identify with its group and vote in concert. However, this cannot be envisaged in share companies with thousands of shareholders. Though the notion will be easier to comprehend in a closely held company, it will be less useful in the dispersed ownership model. In the absence of a clear provision that can be implemented, Ethiopia scores zero for the LLSV (analysis index number 3).

The other important minority protection mechanism the Commercial Code fails to set out under Article $365(1)^{68}$ is the derivative suit mechanism i.e., the

\footnotetext{
${ }^{66}$ Annotations to OECD Principles, supra n. 8, p.42.

${ }^{67}$ Ibid.

${ }^{68}$ It appears that the drafter of the provisions (Prof. Escarra) had initially drafted the provisions in Article 364-367 with the aim of providing for derivative suit mechanisms. This seems evident from his Exposé des Motifs in which he states:
} 
right to initiate suits against directors or third parties on behalf of the company. Since directors act on behalf of the company, it becomes difficult to enforce claims on behalf of the company if the redress is to be sought from the directors themselves. ${ }^{69}$ On top of that, directors may forgo legitimate claims of the company against third parties due to collusion with outside business partners or in return for some illicit consideration. ${ }^{70}$ Therefore, where any shareholder considers that the company should be taking legal proceedings against directors or some third party, but neither the board nor the general meeting does so, the right to take action on behalf of the company should pass to individual shareholders ${ }^{71}$ subject to defined conditions in order to prevent abuse of rights. The OECD Principles also incorporate this element under Principle number III. A.2. Annotations to these principles emphatically stress the importance of derivative suits:

Experience has shown that an important determinant of the degree to which shareholder rights are protected is whether effective methods exist to obtain redress for grievances at a reasonable cost and without excessive delay. The confidence of minority investors is enhanced when the legal system provides mechanisms for minority shareholders to bring lawsuits when they have reasonable grounds to believe that their rights have been violated. ${ }^{72}$

Ethiopia again fails on this index. A shareholder's right to challenge decisions of the general meeting (anti-block holder provision in Pistor's analysis or the oppressed minority mechanism in LLSV analysis) is provided under Article 416(2-5). Article 463 also gives minorities the right to withdraw from the company when fundamental changes are made to the Articles of Association, or to the company. Thus, Ethiopia scores one point for the index of oppressed minority mechanism in the LLSV index number 5 . The one share one vote index

"These very important provisions regulate the liability of directors and the procedure for enforcing this liability by individual or class action. These articles [...] represent a sufficiently simple and precise statement of one of the most complex problems in company law, i.e., the action which can be brought by each shareholder in the case where the fault of the directors has prejudiced the company's property as well as his own property." See Peter Winship, (1974), Background Documents of the Ethiopian Commercial Code of 1960 (Addis Ababa, Faculty of Law, Haile Sellassie I University) p.64.

It is more probable that, the original rules Prof. Escarra drafted were later changed either by Prof. Jauferet who replaced him upon his sudden death without completing the drafting, or by the Codification Commission.

${ }^{69}$ Hadden, supra n. 21, p.277.

${ }^{70}$ Ibid.

${ }^{71}$ Ibid .

${ }^{72}$ Annotations to OECD Principles, supra n. 8, p. 41. 
of LLSV index is met in Ethiopia as Articles 347(3) and 407(2) of the Commercial Code precisely provide for this right. So here will be one more point for Ethiopia.

Generally, the minority protection regime of the Commercial Code meets two of the six criteria from Katharina Pistor's index, and two of the five points in the LLSV index. Given that the protections lacking under the Code are the most important ones that can minimize minority shareholder exploitation by managers and/or block holders, it can be said that the law is inadequate in shareholder protection.

But a slight twist can raise the scores to four in these indices. For instance the cumulative voting under Article 352 can say what it is supposed to mean with a slight revision. So does the question of proxy voting by mail. As to derivative suit it appears that the drafter initially set out to provide the mechanism clearly and it was somewhat later on that the procedure was deleted. ${ }^{73}$

Pistor further elaborates these minority protection indices under four headings: voice, exit, anti-manage, and anti-block. Voice rights refer to shareholder control of the company through voting rights and shareholder suits, and in particular include the rights that minority shareholders are entitled to, such as the right " to call an audit commission, a minimum quorum requirement for shareholder meeting to take binding decisions, super- majority requirement for adopting decisions that affect the existence of the corporation in its current form" and " the possibility to fire directors and managers at any time without cause, and the absence of provisions that mandate employee or state representation on the board." 74

The exit index is composed of rules that facilitate shareholders to leave the company such as provisions that protect the right to sell shares without prior approval by other shareholders or the directors, absence of extensive formal requirements for selling one's shares, and rules that facilitate exit by shareholders in case of takeovers and other major transactions that may endanger their position in the company. ${ }^{75}$ Anti-manage index comprises rules that aim to protect shareholders against management such as the right to sue management, rules against self-dealing, rules that require management to abstain from or disclose transactions that compromise their loyalty to the company. ${ }^{76}$ Anti-block rules include provisions that put forth the rights to

\footnotetext{
${ }^{73}$ See supra n. 68.

${ }^{74}$ Pister, supra n. 16, p. 10.

${ }^{75}$ Ibid, p. 11.

76 Ibid.
} 
challenge decisions of shareholders meeting with the view to limiting or avoiding opportunism by controlling block-holders. ${ }^{77}$

While these protections are available at varying degrees in different legal systems, the better their level is in a system, the higher will be the level of minority protection. ${ }^{78}$ Translated into LLSV hypothesis, the higher will be dispersion of ownership and the separation from control. Better protection of these rights encourages small investors to buy shares giving rise to higher level of dispersion. The theory is simple: A good minority shareholder protecting law coupled with a good enforcement system will drive capital into companies, since the share buying public will have no reason to fear as the legal system gives it protection. ${ }^{79}$

If, on the other hand, minority right protection is poor, it would tend to give way to a pattern of concentrated ownership. There are at least two reasons why the ownership pattern in such systems will be more concentrated:

First, large or even dominant, shareholders who monitor the managers might need to own more capital, citrus paribus, to exercise control rights and thus to avoid being expropriated by the managers. This would be especially true when there are some legal or economic reasons for large shareholders to own significant cash flow rights as well as votes. Second, when they are poorly protected, small investors might be willing to buy shares only at such low prices that make it unattractive for corporations to issue new shares to the public. Such low demand by minority investors for corporate shares would indirectly stimulate ownership concentration. With poor investor protection, ownership concentration becomes a substitute for legal protection because only large shareholders can hope to receive a return on their investment. ${ }^{80}$

Through time, a regime which offers poor minority protection will attract mostly block-holders making concentrated ownership prevail. A minority protective regime on the other hand can boost the confidence of investors, and strengthen the capital market. Annotations on the OECD Principles on Corporate Governance states that "investor confidence that the capital they provide will be protected from misuse or misappropriation by corporate managers, board members or controlling shareholders is an important factor in capital markets." ${ }^{\prime 1}$ And, such confidence means that small investors will be willing to pay a better price for shares offered for sale, which in turn lowers the cost of capital for

\footnotetext{
${ }^{77}$ Ibid.

${ }_{79}^{78}$ La Porta et al, supra n. 6, p.1152.

${ }^{79}$ Ibid.

${ }^{80}$ La Porta et al, supra n. 6, p.1145.

${ }^{81}$ Annotations to OECD Principles, supra n. 8, p. 40.
} 
firms that sell equity. Moreover, most controlling shareholders will be content to unwind their holdings first because the law will largely preclude them from exploiting their position; and secondly they will not need to privately monitor the managers since the law takes over that task. ${ }^{82}$ They will rather prefer to diversify their portfolio in such a scenario, than concentrate it.

Despite its persuasiveness, the above justification fails to explain the historical development of dispersed ownership in the USA and UK from which the model was widely copied elsewhere. ${ }^{83}$ Neither in the USA nor in the UK did strong minority shareholder protection precede dispersion of ownership. ${ }^{84}$ This is partly explained by the typical characteristics of commercial law development that "legislative action seems likely to follow, rather than precede, the appearance of securities markets; in substantial part because a self-conscious constituency of public investors must first arise before there will be political pressure for legislative reform that intrudes upon the market." ${ }^{~} 5$ This does not, however, mean that the level of protection of minority shareholders does not affect ownership patterns. The empirical evidence compiled by LLSV, over forty-nine countries has shown that there is a consistent association between diffuse ownership and high level of minority protection on the one hand, and poor minority protection and concentrated ownership, on the other. ${ }^{86}$

There is however one thing that should not be left unsaid about the development of diffuse ownership in UK and USA. Minority investors were not left at the complete mercy of managers and or controlling shareholders. In both countries self regulation by stock exchanges played an important role by ensuring corporate disclosure, furnishing strict listing requirements, and controlling insider dealing and self dealing by managers and block holders. ${ }^{87}$ What this implies is that self regulation by stock exchanges can make up for lack or deficiency of the law in protecting minority rights.

\section{2- Political Ideology}

Assuming that the protection of strong minority equity holders does not cause diffuse ownership and its superstructure governance model, it means that other causes should account for it. There are various explanations in this line. One

${ }^{82}$ Cheffins, supra n. 18 , p. 6.

${ }^{83}$ Coffee, supra n. 19, pp. 25-44.

${ }^{84}$ Cheffins, Corporate Governance: Australian Experience, supra n 58, p. 30.

${ }^{85}$ Cheffins, supra n. 18, p. 65; see also Fekadu Petros (2008), Effect of Formalities on the Enforcement of Insurance Contracts in Ethiopia, in Ethiopian Journal of Legal Education, 1, p.38.

${ }^{86}$ La Porta et al, supra n. 6, 1126-1151.

${ }^{87}$ Cheffins, Corporate Governance: Australian Experience, supra n. 58, pp. 32-33. 
explanation holds that the pattern of equity ownership correlates with the extent to which a country follows a right wing or a left wing political ideology ${ }^{88}$ Thus, in social democracies, that is, nations with governments that are deeply concerned about distributional issues, that favor employees over investors, and play a larger role in the economy, ${ }^{89}$ there will be greater concentration of ownership. $^{90}$ According to Marc Roe the most ardent proponent of this view, this occurs "because as social democracies prefer the interests of other constituencies to those of shareholders, they will pressure corporate managers to suppress shareholder interests in favor of broader constituencies, and only concentrated large shareholders can effectively compel managers to resist these pressures." 91

This thesis fails to explain why and how diffuse /concentrated ownership emerges. First, no convincing reason exists to show that block-holding will be an effective defense from the pressure to cater for non-shareholder interests. ${ }^{92}$ Secondly, whereas countries such as England have the exemplary form of diffuse ownership they are pure social democracies. On the other hand, East Asian Countries have concentrated ownership without being social democracies. ${ }^{93}$

\section{3- Economy Size}

The other theory advanced to explain why concentration or dispersion arises, looks at the size of the economy. In bigger economies, economies of scale will necessitate bigger companies the financing of which may give rise to wide holding. The assumption is that a few individuals will lack both the ability and willingness to hold big blocks in such companies, than in their smaller counterparts. ${ }^{94}$ In contrast, in countries where small companies dominate, which will more likely be a smaller economy, concentration of ownership will prevail as it will be easier to hold blocks in such companies. ${ }^{95}$ Even a country's trade policy may have impact on the pattern of governance. For example, "a country which offers generous tariff protection for its domestic products will tend to have smaller companies than would otherwise be the case" $" 96$ The rationale is that "the tariff barriers will permit 'under-sized' firms to survive when, under open

${ }^{88}$ Mark Roe cited in id, pp. 22-23.

${ }^{89}$ Ibid.

${ }^{90}$ Coffee, supra n. 19 , p. 71.

${ }^{91}$ Ibid.

${ }^{92} I d .$, p. 72.

${ }_{93}^{93}$ Id., pp. $72-73$.

${ }^{94}$ Cheffins, Corporate Governance: Australian Experience, supra n 58, p. 40.

${ }^{95}$ Ibid .

${ }^{96}$ Id., p. 39. 
market conditions, they would lack the resources and infrastructure required to remain competitive" 97

The "economy size" theory also fails to explain how one form prevails over the other. Simply, it contradicts with glaring realities. If this explanation is correct, why would Germany and Japan, bigger economies than the UK have more concentrated ownership? Why did far smaller economies have diffuse pattern of ownership? ${ }^{98}$ Obviously, the minority right protection explanation appears to be backed by more solid evidence. Given that it is more recent and explores forty-nine economies makes it more convincing.

Drawing back on Ethiopia, what is triggering the growth of dispersion of ownership is not clear. The rise of inflation might have made saving less attractive for the public, ${ }^{99}$ driving investment towards the widely available publicly offered shares. However, comprehensive study of shareholder profiles needs to be conducted along with the analyses of the volume of savings in banks during the recent period IPO boom. ${ }^{100}$ As such, econometric analyses are beyond the scope of this article, and I shall skip this issue.

As far as share companies engaged in banking business are concerned, there seems to be a governmental policy against block holding. Article 11 (1) of Proclamation 592/2008 which regulates banking business, prohibits any person other than the FDRE Government from holding more than 5 percent of the shares in a bank. Moreover, while Article 2 (11) defines a shareholder who owns 2 percent or more of the shares as an influential shareholder, the Proclamation refers to fitness criteria to be met by such a person under Article 4 (1). The Proclamation also states that a share transfer that will make a person an influential shareholder be approved by the National Bank under Article 10 (1). Taken together, these provisions seem to show that, the government's policy is towards diffuse ownership in financial companies. It is not however clear whether or not there is a clear policy with regard to non financial companies.

${ }^{97}$ Id., p. 40.

${ }^{98}$ See generally La Porta et al, supra n. 6.

${ }^{99}$ In Habesha Cement S.C, for instance more than $40 \%$ of the shareholders have 5000 ETB (5 shares) each which is the minimum allowed holding, whereas $90 \%$ of the shareholders in Buna Bank (i.e., 10, 350 out of 11,500) own less than 100,000 shares each. See Reporter, (Amharic Version) of Oct. 11 Edition. Likewise, in Brehan Bank S.C, the size of shareholders owning less than 100,000 is $95 \%$ percent, (i.e., 5708 out of 6000 shareholders) see, Addis Fortune, Oct.4 Edition.

100 According to Access Capital research, in the year 2009, more than a billion Birr share sale was launched by six companies. See, Access Capital SC, (2009), The Ethiopia Macroeconomic Handout:, p.25. It is not clear whether or not bank deposits dropped by an equivalent amount. 
The most important thing in the context of this article is the implications of the minority right protection thesis for Ethiopia which is witnessing an evolution in the pattern of corporate ownership. The question is should Ethiopia not pursue the policy of encouraging small investors and push the move forward by further protecting minority rights? The answer for this has to be affirmative. If the country needs to create a middle income segment of its population, and if it wants to have big companies that can pool capital from the broader public and compete on global level in post WTO accession, encouraging the public to invest in share companies is an indispensable policy.

The fact that dispersion of ownership is emerging in Ethiopia without legal change should not undermine the importance of such changes. Therefore, the urgency of the need to reform the law towards achieving better minority protection cannot be over-emphasized. On the other hand, even if it is believed that better minority protection has no correlation with diffuse ownership, the need for revising the law along the lines of better minority protection will still be strong. There is already a broad base of minority shareholders in Ethiopia creating a sufficient constituency to justify overhauling the laws and institutions of corporate governance to achieve better corporate governance.

\section{Ownership Pattern and Corporate Performance}

The notion of corporate performance is vague since different tests are needed to measure performance. But, in this section we shall adopt the narrow conception of the profitability of business. The positive relationship between dispersed ownership and liquid stock market is undisputed. Though stock exchanges do not play a capital formation function, ${ }^{101}$ there is a growing body of research suggesting that an active securities market is an engine for economic growth. ${ }^{102}$ Some scholars suggest that diffuse ownership induces better corporate performance since dispersed small shareholders who have a small percentage of their personal wealth tied up in the company will let managers undertake projects that are worth exploiting. Such a hypothesis is maintained by contrasting this possibility to risk-averse block-holders who will tend to discourage risk-taking and avoid potentially lucrative business opportunities. ${ }^{103}$

${ }^{101}$ Araya Debessay and Tadewos Haregework (1994), "Towards The Development of Capital Market in Ethiopia", in Getachew Yoseph and Abdul Hamid Bedri Kello (Edrs.) The Ethiopian Economy: Problems and Prospects of Private Sector Development (Addis Ababa, Proceedings of the Third Annual Conference on the Ethiopian Economy), p. 228.

${ }^{102}$ Coffee, supra n. 19 , p.5.

${ }^{103}$ Cheffins, supra n. 18 , p. 15 
On top of this, management by qualified professionals (which is more often the case in dispersed ownership model companies) gives them some edge. ${ }^{104}$

However, the relationship between governance patterns and corporate success is not indisputably settled as far as empirical observations are concerned. While the findings of some studies have been found to be contrary to the above assumptions that companies with ownership concentration outperform those with diffuse ownership, this was explained by the theory that large shareholders are active monitors of managers and as a result bring value to their investment. ${ }^{105}$ Indeed, measuring corporate performance vis-à-vis governance style seems to be a difficult exercise. For example, in the 1980's German and Japanese companies scored high performance over their American counterparts, and it was at once suggested that America should revisit its corporate governance style in light of the German and Japan models. But the idea immediately subsided and the argument was reversed because since the 1990s US corporations outperformed their German and Japanese counterparts. ${ }^{106}$

Therefore, the contribution of ownership pattern and governance style to performance is not yet conclusively settled. What this implies is that a governance model alone is not the determining factor in as far as corporate performance is concerned. There can be other factors that influence profitability and growth. But corporate governance is not solely about performance. Neither is company law. It is also about the creation and maintenance of a fair and equitable economic relation among investors. Secondly, as set out in the preceding section, the influence that legal rules have in determining the prevalent model is clear. Hence performance should not be the sole basis in making the choice of rules towards the formulation of one model in preference to the other.

\section{Conclusions}

The corporate climate in Ethiopia is changing with the emergence of newer companies with several thousand shareholders who have no control over the company. In such cases, control over the company is left in the hands of a few managers who in the worst case scenario may in turn be controlled by block holders. To borrow the expression of Berle and Means, the rise in separation of ownership and control is giving rise to the "ownership of wealth without appreciable control and control of wealth without appreciable ownership."107

\footnotetext{
${ }^{104}$ Ibid.

105 Ibid, p. 27.

${ }^{106}$ Carver, supra n. 2, p. 87

${ }^{107}$ Berle \& Means, supra n. 7, p. 69
} 
Although such a development is to be encouraged for its overall positive economic impact, there is a need to be cautious that shareholders may be subjected to exploitation in the hands of corporate managers or block-holders. There is therefore, a need to carefully re-design the law with the view to protecting shareholder interests and thereby create a conducive environment for the flow of capital. This significantly requires appropriate laws and institutions which can address the corporate governance problems that can arise under the new context of separation between ownership and control.

The tight regulatory environment under Proclamation 592/2008 within which financial companies, especially banks operate brings their managers and block holders under a strict control of the National Bank. But that does not seem to be enough in protecting minority rights. Financial regulation, which is the objective of the National Bank, is just one aspect of the governance and does not give sufficient solution to the problems minority investors face in these companies. A look at Articles 12-17 of the Proclamation reveals that the objective of the National Bank is not that of protecting minority shareholders. Instead, it pays attention to the protection of depositors and the maintenance of a sound monetary system. This is evident in light of the various provisions of the Proclamation including the ones which give the National Bank power to dismiss or suspend the board of directors or take other drastic measures none of which are contingent upon the request of shareholders. Therefore, the conclusions and recommendations in this article regarding entrenching minority rights hold valid for financial companies as well.

Problems related to corporate governance are similar in all countries. That is why countries such as Japan, Ecuador and Thailand have hybrid company laws ${ }^{108}$ that benefit from the synthesis of different legal traditions and indigenous realities. Ethiopia's Commercial Code is also hybrid. ${ }^{109}$ In his Exposé des Motifs, Professor Escarra explains the selection of best foreign laws while he was drafting the Company Law part of the Commercial Code:

[T] he goal to attain is to encourage one day the investment of Ethiopian savings in large broad based enterprises [....] This is why, without taking into account the so called preference to be given to this or that model in the Continental or the Anglo American legal system, I had always in mind the interest of Ethiopia and I have selected the solutions which I believe to be the best no matter where they come from, on condition that they may be applied to Ethiopian conditions. ${ }^{110}$

${ }^{108}$ La Porta et al, supra n. 6, p.1119.

${ }^{109}$ See Cheffins, Corporate Governance: Australian Experience, supra n. 58, Introduction, p. iii.

${ }^{110}$ Ibid, p. 61. 
The company law section of the Commercial Code can therefore be easily reformed without much problem. There is very little problem of path dependence, if any, in this respect. So both the existing systems of minority protection can be strengthened and new mechanisms can be introduced.

The most important changes that are needed to address the governance problems at the wake of growing separation between ownership and control include strengthening the voice and exit rights of shareholders. With regard to the voice rights, introduction of a derivative suit mechanism seems to be relevant. However, as derivative suits are prone to abuse, sufficient conditions should be provided to prevent abusive exercise of the right. Both as a mechanism of shareholder empowerment and as a good corporate governance practice there should be a better regime of disclosure of corporate information.

Exit rights should be easily available through two mechanisms: One is the introduction of the principle of mandatory bid. Secondly, the oppressed minority exit right under Article 463 should be strengthened. In order to expedite these exit rights there is an urgent need to introduce stock markets. In the absence of organized stock markets there can be no meaningful right of exit. Indeed, this is the most fundamental question that the growth of dispersed ownership in Ethiopia is posing. Moreover, there is adequate shareholding constituency in Ethiopia to support a viable stock market. It is to be noted that only 6000 shareholders had created a relatively functional stock market during Emperor Haile Selassie's reign. ${ }^{111}$ This is almost half of the number of shareholders in Buna Bank (see table 3 supra). Moreover, the absence of a stock market at present may create share illiquidity. In the long run, the public may therefore, be discouraged from buying shares thereby affecting the availability of capital for companies.

A related mechanism of assuring exit rights of shareholders in takeover situations is what is known as mandatory bid rule introduced in England ${ }^{112}$ and transplanted to many parts of the world including EC and Brazil. ${ }^{113}$ According to this rule, a shareholder who acquires control over a company is obliged to buy shares of minorities at the same price he paid for control. This in effect means that minority shareholders are not only guaranteed the right to exit the

\footnotetext{
${ }^{111}$ Pischke, supra n. 51.

${ }^{112}$ John Armour, Simon Deakin, Prabirjit Sarkar, Mathias Siems, Ajit Singh, (2008), Shareholder Protection and Stock Market Development: An Empirical Test of the Legal Origin Hypothesis, Law Working Paper, 108/2008, $<$ http//ssrn.com/abstract=1094355> p.38.

113 Pedro Testa, (2006), Mandatory Bid Rule in the European Community and in Brazil: A Critical View, LL.M Thesis, the London School of Economics and Political Science, p.17.
} 
company when control is transferred from one to the other; they also get a right to share from the control premium. ${ }^{114}$

Other areas such as proxy voting by mail and the requirement of depositing shares during board meetings should be liberalized to the extent possible. There seems to be no significant contention and problem to introduce these changes. The issue of cumulative voting or minority representation in the board may however be ineffective in the context of dispersed ownership unless it is carefully devised. In such cases, cumulative voting may not be a sufficient solution since the problem will not be intra-shareholder struggle. Instead, use of external (independent) board members has been found effective in other legal systems. $^{115}$

The ideal model is to divide the board of directors into executive and supervisory and then assign independent directors in the supervisory board to effectively monitor executive directors. Such supervisory board would be distinct from the executive board and may be composed of both shareholders and external/non shareholders. In the dispersed ownership model this seems to work much better if it is associated with the cumulative voting system. ${ }^{116}$ In order to prevent the influence of managers or block-holders in the selection of external directors, cumulative voting should be used to allow minorities to put their representatives in the supervisory board. But, it may be less productive to use cumulative voting for the election of the executive board members, lest decision making in the executive board should begreatly hampered by dissenting challenges. ${ }^{117}$ Today's business world indeed requires rapid decision making. This seems to cater for the needs of efficient business decision-making, and meanwhile ensure a fair degree of control for minorities.

\footnotetext{
${ }^{114} \mathrm{Id}$., p. 18

115 See for instance the practice in Germany and Japan, in Yoshimichi Hiraide (1998), The Structure of Company Management and Shareholder Control in Japan, in Barry A.K. Rider, et al, (editors), Commercial Law in a Global Context: Some Perspectives in Anglo-Japanese Law (Kluwer Law International, London), p. 153.

${ }^{116}$ Ibid.

${ }^{117}$ Ibid, p. 158 .
} 